\title{
Sexual associations for two species of mutillid wasps (Hymenoptera, Mutillidae), with the description of a new species of Anomophotopsis ${ }^{1}$
}

\author{
Elisa Queiroz Garcia²; Roberto Cambra ${ }^{3} \&$ Gabriel A. R. Melo ${ }^{4}$
}

\begin{abstract}
${ }^{1}$ Contribution nr. 1577 from the Departamento de Zoologia, Universidade Federal do Paraná.
${ }^{2}$ Rua das Petúnias 61, apto 301, 38703-036, Patos de Minas-MG, Brazil. elisaqg@yahoo.com.br

${ }^{3}$ Museo de Invertebrados G. B. Fairchild, Universidad de Panamá, Estafeta Universitaria, Panamá-República Panamá. rcambra@ancon.up.ac.pa ${ }^{4}$ Departamento de Zoologia, Universidade Federal do Paraná, Caixa postal 19020, 81531-980, Curitiba-PR, Brazil. garmelo@ufpr.br
\end{abstract}

\begin{abstract}
Sexual associations for two species of mutillid wasps (Hymenoptera, Mutillidae), with the description of a new species of Anomophotopsis. The sexes of Pseudometocha melanocephala (Perty, 1833) and of a new species of Anomophotopsis are associated based on mating pairs found in the field and also in laboratory mating trials. The previously unknown male of Pseudomethoca melanocephala (Perty, 1833) and both sexes of Anomophotopsis quinteroi Cambra, sp. nov., are described. We present the first distribution record of P. melanocephala from Argentina. Anecdotal data on their mating behavior are also discussed.
\end{abstract}

KEYWORDS. Brazil; Pseudomethoca; sex association; Neotropical.

\begin{abstract}
Associação de sexos em duas espécies de vespas mutilídeas (Hymenoptera, Mutillidae), com a descrição de uma nova espécie de Anomophotopsis. Machos e fêmeas de Pseudomethoca melanocephala (Perty, 1833) e de uma nova espécie de Anomophotopsis foram associados com base em casais em cópula encontrados no campo e em testes em condições de laboratório. São descritos os machos de Pseudomethoca melanocephala (Perty, 1833), que até então permaneciam desconhecidos, bem como machos e fêmeas de Anomophotopsis quinteroi Cambra, sp. nov. Apresenta-se o primeiro registro de P. melanocephala para a Argentina. Dados adicionais sobre os testes de associação sexual são também apresentados
\end{abstract}

PALAVRAS-CHAVE. Associação de sexos; Brasil; Pseudomethoca; Neotropical.

Mutillidae is a cosmopolitan family of aculeate Hymenoptera with strong sexual dimorphism: the males are winged (rarely brachypterous or apterous) and possess a normal apocritan mesosoma, while the females are entirely apterous, and most of them exhibit complete fusion of the mesosomal sclerites (Brothers 1995). This strong sexual dimorphism has prompted descriptions of numerous species based on a single sex (e. g. Nonveiller 1994, Quintero and Cambra 1994, Lelej and Krombein 2001, Pitts and Parker 2003), and also makes sex association based solely on adult morphology almost impossible.

Anomophotopsis Schuster is a Neotropical genus of Sphaeropthalminae, and is known only from Brazil and Argentina. Schuster (1949) erected this genus based on the male of Anomophotopsis lugens (F. Lynch-Arribalzaga, 1878). Casal (1973) considered that A. lugens was probably the opposite sex of Sphinctopsis cometa Gerstaecker, 1874 based on identical morphology of mandibles and similar geographical distribution. Fritz (1993) confirmed this sex association and transferred Sphinctopsis cometa to Anomophotopsis, together with two additional species known only from females, $A$. matrera (Casal, 1973) and A. cometa rubrocalva (Burmeister, 1875). Except that Anomophotopsis species are diurnal, nothing is known concerning the biology of the species belonging to the genus. Here a new species of Anomophotopsis is described, representing the second species in the genus known from the male and the third from the female.
The previously unknown male of Pseudomethoca melanocephala melanocephala (Perty, 1833) is described. Anecdotal information on the mating behavior of these two species is presented.

\section{MATERIALAND METHODS}

Morphological nomenclature follows Cambra and Quintero (2003). Abbreviations used are: metasomal tergum $=\mathrm{T}$; metasomal sternum $=\mathrm{S}$.

Association of conspecific males and females was established by finding mating pairs in the field and by sexual association trails in the laboratory. The sex association trials were carried out in an arena measuring $14 \times 9 \times 4 \mathrm{~cm}$. Two types of trials were used. In the first type, one male was placed with a single female in the arena. In the second type, one male was exposed simultaneously to 12 females belonging to the following six different species: Pseudomethoca melanocephala melanocephala (Perty), Traumatomutilla inermis (Klug), Anomophotopsis quinteroi Cambra, Hoplocrates specularis (Gerstaecker), Darditilla felina (Burmeister), and Ephuta (Ephuta) scenica (Gerstaecker). Each trial lasted for approximately $15 \mathrm{~min}$, with intervals of five minutes between them.

The specimens were collected in 'Mananciais da Serra', in Piraquara, Paraná, Brazil. A narrow dirt road through the forest was surveyed for wandering mutillid wasps during the day 
from November, 2002 to October, 2003. Males were captured with entomological nets and females with forceps. Individuals were kept in the laboratory in small plastic vials $(5 \times 5 \mathrm{~cm})$ and fed diluted honey water and were kept under controlled temperature $\left(25^{\circ} \mathrm{C}, \pm 2^{\circ} \mathrm{C}\right)$, humidity $(70 \%)$ and a photophase of 12 hours.

The abbreviations used in the text for the Institutional collections that house the types or other specimens discussed are: AMNH, American Museum of Natural History, New York, U.S.A.; DZUP, Coleção de Entomologia Pe. J. S. Moure, Departamento de Zoologia, Universidade Federal do Paraná, Curitiba, Brazil; MIUP, Museo de Invertebrados G. B. Fairchild, Universidad de Panamá; USNM, National Museum of Natural History, Washington, U.S.A.

\section{RESULTS}

\section{Anomophotopsis quinteroi Cambra, new species}

(Figs. 1, 2, 5, 6, 8, 11)

Description of holotype male.- Body length $9 \mathrm{~mm}$. Integument entirely black, except for pale white tibial spurs; both simple and also plumose setae present. Head: more or less subglobose and narrowed behind eyes (Fig. 1), as wide as pronotum (including eyes); head, mandible and scape with simple white setae; vertex with dense, moderate-sized punctures (Fig. 1); frons with punctures denser than those on vertex, some confluent; clypeus punctures sparser than those on vertex; clypeus anteriorly produced as convex nasiform plate overlying apices of closed mandibles (Fig. 2); genal carina absent; hypostomal fossa moderate in size; mandible apex bidentate, ventral margin without tooth, not excised; maximum eye diameter $0.88 \mathrm{x}$ distance from lateral ocellus to inner eye margin; ocelli small, lateral ocelli maximum diameter $0.17 \mathrm{x}$ distance from one of them to inner eye margin; scrobal carina reduced to inconspicuous protuberance; antennal tubercles separated by approximately $2.3 \mathrm{x}$ diameter of anterior ocellus; scape with single sharp longitudinal carina, more distinctive on apical half; antenna slender, $1^{\text {st }}$ flagellomere slightly shorter than $2^{\text {nd }}$. Mesosoma: pronotum, scutellum, propodeum, pleural areas and legs with simple white setae; mesoscutum, anterior and inner lateral margins of tegula with simple black setae; punctation on pronotum, mesoscutum, scutellum and mesopleura similar to that on vertex; scutellum convex; tegula convex, smooth and shiny, but with few punctures along anterior and inner lateral margins; dorsal surface of propodeum reticulate; metapleura and lateral surface of propodeum mostly smooth, except for fine rugosities on propodeum near metapleura; humeral angle of pronotum carinate; notauli absent; mesosternum without spines or protuberances; fore and middle coxae without spines or carinae, posterior coxa with an inner longitudinal carina; forewing hyaline, with two submarginal cells and traces of third (Fig. 6). Metasoma: T1 to T5 and all sterna with white setae; T6 and T7 with simple black setae; T1 with apical transverse band of dense, simple white pubescence; T2 to T5 with a densely pubescent, apical transverse band consisting of both, simple and plumose white setae; T1 to T6 with small, sparse punctures; basal half of T7 with small, sparse punctures, the distal half smooth; S1 with sparse punctures; S2 with dense moderate-sized punctures, S3 to S6 with small, close punctures; S7 without distinctive punctures; $\mathrm{T} 1$ completely sessile on $\mathrm{T} 2$, without a constriction separating them; $\mathrm{T} 1$ short, $0.81 \mathrm{x}$ as long as wide; $\mathrm{T} 2$ with lateral felt line, S2 without felt line; T7 without lateral carina delimiting pygidial area; S1 with a medial, longitudinal carina; S7 modified, slightly convex and short, its apical margin not reaching apical margin of T7, the medial area with two longitudinal, distally converging, carinae; paramere (Fig. 8) glabrous, except for few apical setae; dorsal edge of paramere convex in basal two thirds, concave in apical third; ventral edge of paramere concave in basal two thirds, straight in apical third, the two sections forming a sharp angle; penis valve (Fig. 10) without preapical tooth. Volsella with cuspis reduced to a rounded lobe, digitus short.

Description of Allotype female.- Body length $7 \mathrm{~mm}$. Head capsule, mandibles, antennae, mesosoma, including legs, red, except for humeral angles of pronotum black; tibial spurs pale white; metasoma black, except for most of tergum I and entire sternum I red; tergum II with pair of lateral, small, diagonally oval, pale yellow integumental spots (Fig. 5), distance between spots approximately equal to their diameter; setae simple. Head: rectangular, 1.3x as wide as mesosoma (including eyes); vertex and frons with sparse setae of diferent colors, white and black; gena, clypeus, scape and mandible with white setae; vertex, frons and gena with moderate, very close punctures, interspaces less than half the width of punctures; scrobal carina present, without tooth; antennal tubercles separated by $2.0 \mathrm{x}$ their diameter; antenna slender, $1^{\text {st }}$ flagellomere $1.7 \mathrm{x}$ as long as $2^{\text {nd }}$; genal carina present, not reaching base of mandible, without an anterior or posterior tooth; clypeus with anterior margin almost straight, medial area with an arcuate, transverse, ridge ending in anterior margin as distinctive tubercle in front of each antennal tubercle; carina present from posterior articulation of mandible to margin of hypostomal fossa; mandible apex bidentate, ventral margin without any tooth or process, not excised. Mesosoma: 1.1x as long as wide in dorsal view, excluding anterior collar; narrowing gradually toward propodeal spiracle, slightly broadening posteriorly (Fig. 5); without patterns of white or black pubescent bands, dorsum with dark setae; pronotum laterally and mesopleura with white pubescence; metapleura and lateral area of propodeum glabrous; punctation on pronotum similar to that on head, becoming larger and confluent on mesonotum and anterior half of dorsum of propodeum; posterior dorsal half of propodeum almost smooth; mesopleura micropunctate; metapleura and lateral area of propodeum smooth; humeral angle carinate; lateral margins of mesonotum and propodeum without spines or teeth; fore and middle coxae without spines or carinae, posterior coxa with a inner longitudinal carina; dorsal surface of mid and posterior tibiae with two rows of three to four spines. Metasoma (Fig. 5): terga and sterna with white setae; T1 and S1 with a few, small, very sparse punctures; T2 

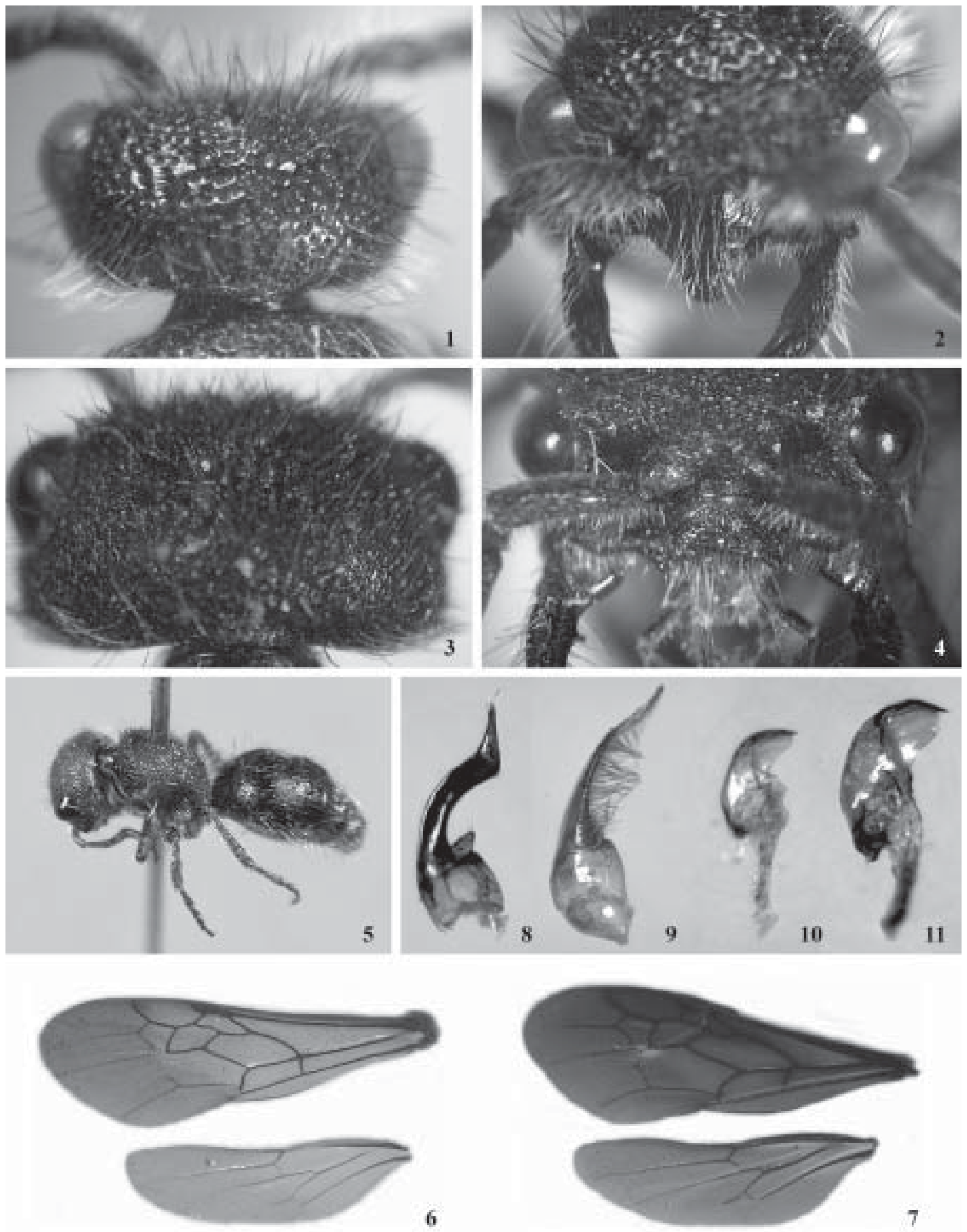

Figs. 1-11. Species of Anomophotopsis and Pseudomethoca. 1-2, A. quinteroi Cambra sp. nov., male. 1, head, dorsal view. 2, clypeus, frontal view. 3-4, P. melanocephala, male. 3, head, dorsal view. 4, clypeus, frontal view. 5, A. quinteroi Cambra sp. nov., female, dorsolateral view. 67, fore and hindwing. 6, A. quinteroi Cambra sp. nov. 7, P. melanocephala. 8-11, male genitalia, lateral view. 8, A. quinteroi Cambra sp. nov., paramere. 9, P. melanocephala, paramere. 10, A. quinteroi Cambra sp. nov., penis valve. 11, P. melanocephala, penis valve. 
to $\mathrm{T} 6$ and $\mathrm{S} 3$ to $\mathrm{S} 6$ with small, close punctures; S2 with moderate, in size, sparse punctures; $S 1$ with a medial, longitudinal carina; T2 with lateral felt line, S2 without felt line; T7 with lateral carina delimiting a smooth pygidial area.

Type material.- Holotype male, Brazil: Paraná, Piraquara, Mananciais da Serra, 2530'S 4859'W, 27 February 2003, E. Q. Garcia. Allotype female, same data as holotype, except 5 February 2003; additional paratypes, same data as holotype except 30 November 2002, 4 females; 20 December 2002, 1 female; 16 January 2003, 1 female; 30 January 2003, 1 female and 1 male; 2 February 2003, 1 female; 5 February 2003, 4 females; 8 February 2003, 1 male; 19 February 2003, 7 females, 5 males; 1 March 2003; 2 females, 2 males; 14 March 2003, 4 females. Holotype, allotype and additional paratypes deposited at DZUP, except for one male and one female paratypes at MIUP.

Diagnosis.- The male of Anomophotopsis quinteroi differs from other New World mutillids by the combination of a nasiform clypeus, presence of two longitudinal carinae in the medial area of the S7 and the paramere ventral edge concave on the basal two thirds, straight on the apical third, with the two regions forming a sharp angle. Males of Anomophotopsis quinteroi and A. cometa cometa (Gerstaecker) - the only other male species known in Anomophotopsis — can be separated as follows: A. quinteroi has the apex of the nasiform clypeus convex, the mesosoma black, the medial area of S7 with two longitudinal carinae, $\mathrm{T} 2$ to $\mathrm{T} 5$ with a dense apical transverse band of both simple and plumose setae, and by the shape of paramere ventral edge, while in A. cometa cometa, the apex of the nasiform clypeus is bilobed, the mesosoma integument is red except for the black pronotum, the medial area of S7 lacks longitudinal carinae, T4 and T5 lack dense apical band of both simple and plumose setae, and the paramere has dense setae on dorsal and ventral edges with the ventral edge almost straight. The known females can be separated as follows: $A$. quinteroi lacks spines or teeth in the lateral margin of mesonotum while in A. cometa and A. matrera, there are two teeth in the lateral margin of mesonotum; A. quinteroi and $A$. cometa have the frons and vertex with very dense punctures, and T2 with two pale yellow integumental spots; while $A$. matrera, has the frons and vertex very sparsely punctured and T2 has two white pubescent maculae; in A. quinteroi and A. matrera, the legs are red, while in A. cometa, they are black.

Etymology.- This species is named in honor of Diomedes Quintero A., for his contributions to the knowledge of Neotropical Mutillidae.

Comments on sex association.- Sex association was based on one mating pair found in the field and on laboratory mating trials. In three of the four mating trials in which a male of Anomophotopsis quinteroi was placed with females of Anomophotopsis quinteroi, the male tried to mate with the females. In $15 \mathrm{~min}$ of exposure, an average of $3.33( \pm 0.58)$ mating attempts were observed. The mating attempts consisted of a sequence of behaviors in which the male walked or flew toward the female, beating and vibrating his wings in rapid bursts, and when they were in close contact, he climbed on the female dorsum, holding her with his legs. In all attempts, the females refused to mate and tried to dislodge the male by pushing on him with the hind legs. These males displayed no obvious courtship behavior toward females of other species. In the multifemale trials, the males of Anomophotopsis quinteroi did not exhibit any mating attempts.

\section{Pseudomethoca melanocephala melanocephala (Perty)} (Figs. 3, 4, 7, 9, 11)

Mutilla melanocephala Perty, 1833, Delect. Anim. Artic. Brasil, p. 137 , female.

Sphinctopsis melanocephala: Mickel, 1928, Bull. U.S. Nat. Mus. 143: 37.

Pseudomethoca melanocephala: Mickel, 1937, Rev. Ent. 7: 183; Quintero and Cambra (1996) [taxonomic position].

Male description.- Body length 11-12 mm. Integument entirely black except for pale white tibial spurs; setae simple. Head: more or less rectangular in dorsal view (Fig. 3) as wide as pronotum (including eyes); vertex and frons with erect and recumbent black setae; gena with recumbent black setae and erect white setae; clypeus, mandible and scape with white setae; vertex (Fig. 3), frons, gena and clypeus with dense, small, close punctures, without spaces between punctures, some punctures confluent; anterior margin of clypeus arcuate, with a distinctive lateral tooth aligned under each antennal tubercle (Fig. 4); genal carina absent; hypostomal fossa moderate in size; dorsal margin of mandible with small tooth near its base, apex bidentate (Fig. 4), ventral margin without tooth, not excised; maximum diameter of eye $0.75 \mathrm{x}$ distance from lateral ocellus to inner eye margin; ocelli small, maximum diameter of lateral ocelli 0.16x distance from one of them to inner eye margin; scrobal carina reduced to inconspicuous protuberance; antennal tubercles separated by $2.3 \mathrm{x}$ diameter of anterior ocellus; scape with single sharp longitudinal carina on apical half; antenna slender with $1^{\text {st }}$ flagellomere more or less of same length than $2^{\text {nd }}$. Mesosoma: most of pronotum, mesoscutum, most of scutellum, anterior and inner lateral margins of tegula with black setae; humeral angles of pronotum, scutellum postero-laterally, metanotum, propodeum, pleural areas and legs with white setae; similar punctures on head, pronotum and mesoscutum; scutellum convex, more coarsely punctured; tegula convex, smooth and shiny, but with few punctures along anterior and inner lateral margins; dorsal surface of propodeum reticulate, its lateral surface partly reticulate, with smooth and finely rugose areas near metapleura; propleura and mesopleura with sparse small punctures, weakly aciculate between punctures; metapleura almost smooth, very sparsely micropunctate; humeral angle of pronotum carinate; notauli absent, mesosternum without spines or protuberances; fore and middle coxae without spines or carinae, posterior coxa with inner longitudinal carina; forewing infuscated, with two submarginal cells and traces of a third (Fig. 7). Metasoma: segment I, lateral areas of T2 to T6, S2 to S7 with white setae, remainder of terga with black setae; 
T1 to T6 with small, close punctures, those on T2 to T6 confluent; basal half of $\mathrm{T} 7$ with large close punctures, distal half weakly rugose; S1 almost smooth, with small, sparse punctures; S2 with moderate punctures, separated from one another by one to two puncture diameters; S3 to S7 with small, close punctures; T1 completely sessile on T2, without a constriction separating them; $\mathrm{T} 1$ short, $0.82 \mathrm{x}$ as long as wide; $\mathrm{S} 1$ with medial, longitudinal carina; $\mathrm{T} 2$ with lateral felt line, S2 without felt line; T7 with short lateral carina delimiting pygidial area; S7 simple, slightly flattened, with apical margin more or less straigth; paramere (Fig. 9) with densely set setae on dorsal and ventral edges; dorsal edge of paramere convex, ventral edge almost straight; penis valve (Fig. 11) without preapical tooth.

Specimens examined.- Brazil: Parana, Piraquara, Mananciais da Serra, 253' S 48 59' W, 1 Feb 2003, E. Q. Garcia, 1 male (MIUP); same data but: 8 Feb 2003, 1 male (DZUP); 5 Feb 2003, 1 female (MIUP); 16 Jan 2003, G. Melo \& E. Q. Garcia, 1 male, 1 female (DZUP); Viçosa, MG, Mar 1995, R. C. Peruqueti, 1 female (MIUP); Sta Catarina, Corupá, A. Maller: Jan 1953, 2 females (USNM, AMNH), Feb 1952, 2 females (AMNH). Argentina: Misiones, Iguazu, 30 Jan 1985, 1 female (MIUP). This is the first record of P. melanocephala for Argentina.

Distribution.- Brazil and Argentina.

Diagnosis.- In Mickel's (1935) revised key to North American males of Pseudomethoca species, this species runs to the end of couplet 15 . The male of $P$. melanocephala is related to $P$. simillima (Smith, 1855) from the U.S.A. Males of $P$. melanocephala have bidentate mandibles, body with black and white setae, punctures confluent on T2 to T6, and distal half of pygidial area weakly rugose, while in $P$. simillina, the mandible apex is tridentate, body setae almost totally white (a few black setae on the two distal segments of metasoma), distal half of pygidial area with longitudinal striae, and punctures on T2 to T6 not confluent. Only 13 described male species of Pseudomethoca are known from Mexico to South America. In a manuscript key to Neotropical described males of Pseudomethoca, P. melanocephala is most similar to $P$. zapoteca (Blake, 1871) from Mexico. Males of $P$. melanocephala have bidentate mandibles, tegula convex, and the metasoma with setae of diferent colors, black and white, while $P$. zapoteca has mandibles tridentate, the posterior part of the tegula bends downward forming a posterior surface at a sharp angle with the dorsal surface, and the metasoma is covered with pale golden setae.

Comments on sex association.- Sex association was based on laboratory mating trials, as well as on males and females of P. melanocephala reared from the same host (B. Blochtein, pers. comm.). In all tests where males of Pseudomethoca melanocephala were placed with conspecific females, the males tried to mate with the females. In 15 min of exposure, an average of $14.5( \pm 2.43)$ mating attempts were observed. The attempts started immediately after the introduction of the female into the arena. The behavioral sequence exhibited by males of $P$. melanocephala was the same as described above for A. quinteroi. The females refused to mate by dislodging the male with their hind legs. The males showed no interest toward females of other species. In all multifemale trials, the males were attracted to and attempted to mate only with females of $P$. melanocephala. During the 15 min exposure, an average of $2.33( \pm 1.15)$ mating attempts was observed.

Comments on field behavior: Females of Pseudomethoca melanocephala were found from January to May, 2003. Those observed in February presented a distinct behavior; while walking, they moved periodically their metasoma up and down, while at the same time, exposing the sting. This behavior was exhibited also by some females brought to the laboratory.

\section{DISCUSSION}

The sequence of courtship behaviors exhibited by male Pseudomethoca melanocephala and Anomophotopsis quinteroi is similar to that reported for other species of Mutillidae, e.g., Pseudomethoca frigida (Brothers 1972), except that males of these two species did not make short, hopping flights when approaching females. However, these short flights might not have been observed simply because the setup used to carry out the sex association trials.

According to Brothers (1972), females of Mutillidae apparently mate only once, immediately after their emergence. This could explain why the females refused to mate in the laboratory trials. Most likely they had already mated when found in the field.

The behavior exhibited by females of Pseudomethoca melanocephala of moving the metasoma up and down is reported for the first time in a member of the Sphaeropthalminae. This behavior has been described for Ephuta slossonae, a Nearctic species of Mutillinae, by Krombein and Norden (1996) and observed also in other species of Neotropical Ephuta by Quintero and Cambra (1996). However, none of those accounts reported exposure of the sting. As suggested by these authors for Ephuta species, this behavior in Pseudomethoca melanocephala might be related to dispersion of pheromones into the air to attract males.

Acknowledgments. We thank Diomedes Quintero A. (Universidad de Panama) and Annette Aiello (Smithsonian Tropical Research Institute) for improving the manuscript and for other assistance; Betina Blochtein, Pontificia Universidade Católica do Rio Grande do Sul, for loan of reared specimens of Pseudomethoca melanocephala.

\section{REFERENCES}

Brothers, D. J. 1972. Biology and immature stages of Pseudomethoca f. frigida, with notes on other species (Hymenoptera, Mutillidae). The University of Kansas Science Bulletin 50: 1-38.

Brothers, D. J. 1995. Mutillidae, pp. 541-548. In: P. E. Hanson \& I. D. Gauld (eds.). The Hymenoptera of Costa Rica. Oxford University Press, 893 p.

Cambra, R. A. \& D. Quintero. 2003. Description of the previously unknown male of the Neotropical genus Hoplognathoca Suarez and new distribution records (Hymenoptera: Mutillidae: 
Sphaeropthalminae). Transactions of the American Entomological Society 129: 487-495.

Casal, O. H. 1973. Las especies relacionadas con Sphinctopsis cometa cometa (Gerstaecker, 1874) (Hymenoptera, Mutillidae). Physis 32: $15-18$.

Fritz, M. 1993. Notas sinonimicas de Mutillidae Neotropicales (Hymenoptera). Revista Chilena de Entomologia 20: 9-11.

Krombein, K. V. \& B. B. Norden. 1996. Behavior of nesting Episyron conterminus posterus (Fox) and its cleptoparasite Ephuta s. slossonae (Fox) (Hymenoptera: Pompilidae, Mutillidae). Proceedings of the Entomological Society of Washington 98: $188-194$.

Lelej, A. S. \& K. V. Krombein. 2001. Review of the Oriental mutillid wasps of the subfamily Ticoplinae (Hymenoptera, Mutillidae). Far Eastern Entomologist 99: 1-18.

Mickel, C. E. 1935. Descriptions and records of Nearctic mutillid wasps of the genera Myrmilloides and Pseudomethoca (Hymenoptera: Mutillidae). Transactions of the American Entomological Society 61: $383-398$.

Nonveiller, G. 1994. Description du nouveau genre Afrotropical
Spinulomutilla et de onze especes nouvelles (Hymenoptera: Mutillidae). Annales de la Société Entomologique de France 30: $329-344$.

Pitts, J. P. \& F. D. Parker. 2003. Description of the female and larval stage of Odontophotopsis succinea Viereck (Hymenoptera: Mutillidae), with new synonymy and notes. Zootaxa 137: 1-10.

Quintero, D. \& R. A. Cambra. 1994. Systematics of Pseudomethoca areta (Cameron): Sex association, description of the male and gynandromorph, and a new synonymy (Hymenoptera: Mutillidae). Journal of Hymenoptera Research 3: 303-308.

Quintero, D. \& R. A. Cambra. 1996. Contribución a la sistemática de las mutilidas (Hymenoptera) del Perú, en especial las de la Estación Biológica BIOLAT, Río Manu, Pakitza, pp. 327-357. In: D. E. Wilson \& A. Sandoval (eds.). Manu: The Biodiversity of Southeastern Peru. Washington DC, Smithsonian Institution Press, $679 \mathrm{p}$.

Schuster, R. M. 1949. Contributions toward a monograph of the Mutillidae of the Neotropical Region. III. A key to the subfamilies represented and descriptions of several new genera (Hymenoptera). Entomologica Americana 24: 59-140.

Received 27/06/2005; accepted 24/07/2006 